\title{
A RE-EXAMINATION OF RATIFICATION
}

\section{JeNNIFER PAYNE*}

THE issue of ratification is one whose "tentacles creep into every part of company law". ${ }^{1}$ When a wrong has been done to the company, it is the mechanism which determines whether that wrong can be put right, and, if it can be, whether it will be; whether the wrongdoers ought to be released from their liability, and, ultimately, whether litigation can and will be commenced. That is a lot to ask of a single doctrine, and it is not, therefore, surprising to find that this topic has been described as being "singularly muddled". ${ }^{2}$ The confusion has not been helped by the fact that the courts have often avoided tackling this difficult area head on, one judge going as far as to say "I do not think that it is necessary, nor do I feel competent to disentangle the many threads of principle in this tangled skein". ${ }^{3}$ The Law Commission has also said that the "law on ratification is by no means clear" 4 but has failed to tackle the complexities of the issue, stating that "[a]lthough there may be a need for modernising and simplifying the law of ratification, we are of the firm view that any changes need to be considered in the context of a comprehensive review of directors' duties." 5 However, when recently given such an opportunity the Law Commission ${ }^{6}$ did not consider any changes to the law regarding ratification. ${ }^{7}$

This article aims to cast at least a little more light on this complex issue. It will begin with an analysis of the origins of the concept of ratification, will then discuss how well that concept has been translated into modern company law, and will finally examine some of the different approaches to ratification which are available to the court.

* Fellow of Merton College, Oxford. I would like to thank Richard Nolan and Professor Len Sealy for their comments on an earlier draft of this article. Any errors remain entirely my own.

1 K. W. Wedderburn "Derivative actions and Foss v. Harbottle" (1981) 44 M.L.R. 202, 212.

2 R. Cranston, "Limiting Directors' Liability: Ratification, Exemption and Indemnification" [1992] J.B.L. 197, 199

3 Winthrop Investments Ltd. v. Winns Ltd. [1975] 2 N.S.W.L.R. 666, 671 per Glass J.A.; and K. Yeung, "Disentangling the Tangled Skein: The Ratification of Directors' Actions" (1992) 66 A.L.J. 343.

4 Law Commission Report No. 246, Shareholder Remedies, para 6.81.

$5 \mathrm{Ibid}$, at para. 6.85. The Law Commission rather blandly recommended that, in relation to its new derivative action ratification should continue to be effective in the cases where it is currently effective, to bar an action by a minority shareholder, but will otherwise be only a factor to which the court has regard (para. 6.84).

${ }^{6}$ In its Consultation Paper "Company Directors: Regulating Conflicts of Interest and formulating a Statment of Duties" (No. 153)

7 It contented itself with a restatement of some of the principles regarding ratification: paras. 11.30-11.38. However, it should be said that the Law Commission's terms of reference were rather limited in this Consultation Paper: paras. 1.2-1.4. 


\section{A. RELEASE AND RATIFICATION}

Before continuing, though, a few words need to be said about a distinction which has been drawn between release and ratification. "Release" refers to the release of the trustees, or, in a company context, directors, from their personal liability for their breach of duty. "Ratification" relates to the validation of the act done by the director in breach of his duty. For example, where a director negotiates a contract, but acts beyond the scope of his authority in doing so, any "ratifying" action by the shareholders potentially needs to address two issues: the director's breach of duty and the validity of the contract. The distinction between release and validation has been increasingly recognised by academics ${ }^{8}$ and has been made by parliament in some circumstances. ${ }^{9}$ This may be a helpful distinction to draw in some situations because different considerations may well arise in relation to each issue.$^{10}$ However, it is probably fair to say that this distinction has not generally been drawn in practice. Instead, it is generally assumed that a "ratifying" ordinary resolution of the shareholders will have both effects.

In fact this differentiation is of less importance where the wrongdoers are also the directors of the company and are in control of the shareholders' meeting, where, for example, the director is standing on both sides of a contract with the company and has not declared his interest, or full value has not been given, or there are other reasons to suspect that the company's interests are not being protected. In such circumstances, whether personally to forgive the director and whether to allow the transaction to go ahead are often effectively the same issue and, therefore, the same considerations ought to apply: no distinction between "release" and "ratification" will generally be necessary. ${ }^{11}$ This article will concentrate on the situation in which the wrongdoers are the directors and are in control, since this is when the concept of ratification becomes most "singularly muddled". Little will therefore be made of the distinction between release and validation in this article, and, therefore, the word "ratification" continues to be used to refer to both processes.

\section{B. The Origins of the ConcePt of Ratification in Company LaW}

In simple terms, ratification has been explained as the process by which "those to whom duties are owed may release those who owe the duties

8 See R. J. C. Partridge, "Ratification and the release of directors from personal liability" [1987] C.L.J. 122; Yeung, at note 3 above; Cranston, at note 2 above.

9 Section 35 Companies Act 1985 (as amended) requires a special resolution by the shareholders in order to allow a company to rely on an ultra vires act against a third party and a separate special resolution to release the directors from their breach of duty in allowing the company to act in an ultra vires manner.

10 See Yeung, at note 3 above.

11 After all, where "the company is defrauded by outsiders ... or by insiders of a minor kind" (Wallersteiner v. Moir (No. 2) [1975] 1 All E.R. 849, 857 per Lord Denning M.R) the principle of ratification works reasonably well, because there is then no reason to doubt that those acting on the company's behalf in resolving to ratify are, in fact, acting in the company's interests (whether that is in fact the case or not) and therefore no reason for the courts to interfere with the concept of majority control. 
from their legal obligations ... prospectively ${ }^{12}$ or retrospectively". ${ }^{13}$ This process, like many of those found in company law ${ }^{14}$, seems to have originated in trust law. Where there are only two groups involved, the trustee and the beneficiary, the principle is relatively straightforward. A beneficiary who consents to a breach of trust before it occurs ${ }^{15}$ or releases the trustees following the breach ${ }^{16}$ will not subsequently be able to succeed in a claim for breach of trust against those trustees provided the consent or release is done in full knowledge of the facts ${ }^{17}$, by someone of full age and capacity ${ }^{18}$ and where no undue influence has been applied. ${ }^{19}$ The release of a trustee in this way is clearly a personal right belonging to the beneficiary. Accordingly, the consent or release of one beneficiary will not bind another ${ }^{20}$, so that if a trustee wishes to ensure that no breach of trust action will be brought, the unanimous consent or release by the relevant beneficiaries at the time of the breach would be required. ${ }^{21}$

The concept of release operates in this way because all of the trustees' duties are owed to the beneficiaries. They are the right individuals to bring an action against the trustees for breach of trust and therefore they are the right individuals to release the trustees. Since the right of release is personal, each beneficiary need only consider his or her own wishes when determining whether or not he or she will grant a personal release to the trustees: the beneficiary has no obligation to consider anyone else's interests in making this decision.

If we return to the distinction between "release" and "ratification" for a moment it can be seen that the trust principle of release equates to the idea of releasing the directors from their breach of duty, rather than validating the wrongful act. This makes sense given the fact that, unlike a company,

12 Technically, a prospective release is not a "ratification", but rather a conferring of future powers. There may be some practical points of difference, for example more detailed disclosure may be required for a retrospective release rather than a prospective one, but the distinction is not an important one for the purposes of this article, and therefore the term "ratification" will be used to apply to both.

13 Gower, Principles of Modern Company Law, 6th ed., by Paul Davies (London 1997) (hereafter "Gower"), p.644.

14 See e.g. Gower, p.598 and Ch.s 2 \& 3; L. S. Sealy, "The Director as Trustee" [1967] C.L.J. 83.

15 Brice v. Stokes (1805) 11 Ves. 319: Nail v. Punter (1832) 5 Sim. 555 and see Spellson v. George (1992) 26 N.S.W.L.R. 666.

16 Farrant v. Blanchford (1863) 1 De G.J. \& Sm. 107.

17 Farrant v. Blanchford (1863) 1 De G.J. \& Sm. 107, although difficult issues arise as to what the knowledge must relate to: what the beneficiary is doing or what the legal effect of his actions are. Perhaps the best view is simply that "the court has to consider all the circumstances in which the concurrence of the cestui que trust was given with a view to seeing whether it is fair and equitable that, having given his concurrence, he should afterwards turn around and sue the trustees: that, subject to this, it is not necessary that he should know what he is concurring in is a breach of trust, provided that he fully understands what he is concurring in, and that it is not necessary that he should himself have directly benefited from the breach of trust": Re Pauling's Settlement [1961] 3 All E.R. 713, 730 per Wilberforce J.

18 Overton v. Bannister (1844) 3 Hare 503.

19 Farrant v. Blanchford (1863) 1 De G.J. \& Sm. 107; Lloyd v. Attwood (1859) 3 De G. \& J. 614

20 Brice v. Stokes (1805) 11 Ves. 319; Ghost v. Waller (1846) 9 Beav. 497.

21 In fact it will be necessary for all those who can benefit under a trust, not just those in existence, to completely release the trustees in this way, under the principle in Saunders v. Vautier (1841) Cr. \& Ph. 240, see, for example, Haynes v. Haynes (1866) 35 L.J. Ch. 303. 
a trust has no legal personality separate to its trustees. When third parties enter into contracts with the trustees (the legal owners) they are not concerned with whether the trustees' acts "bind the trust" in any way. The contract will bind the trustees as individuals, whether they act rightfully or wrongfully in relation to the trust. The issue of "validation" of the contract therefore does not arise for either the third party outsiders or, indeed, the beneficiaries. Instead what is of concern to the beneficiaries is whether the (contractually bound) trustees have rights of indemnity against the trust fund. ${ }^{22}$ They will only do so where the trustees acted correctly in the context of the trust fund. ${ }^{23}$ The beneficiaries then are concerned with whether or not to prevent or allow such indemnity for the trustees, in short, whether to release the trustees from their wrongful acts. ${ }^{24}$

However, since, as stated, the distinction between "validation" and "release" is not of great importance in this article, the trust concept of release will be compared directly with the company law concept of ratification which combines release and validation.

\section{How does the Trust Concept of Release Apply to a Modern COMPANY?}

The trust principle of release was able to be translated fairly neatly into deed of settlement companies, ${ }^{25}$ whose members were the company, so that again only two groups were involved: those acting for the members, ${ }^{26}$ and the members themselves. The directors of these companies were able to contract as agents of the members ${ }^{27}$ and were, on that basis, subject to the direction and control of the members' decisions in general meetings. The members could unanimously ratify or acquiesce in any irregularity of the directors since their "unanimous voice was an authority superior to the deed itself". ${ }^{28}$ However, in relation to modern companies the smooth translation of these trust law principles is hindered by three important principles: the separate legal personality of the company, the concept of majority control, and the idea that a vote is a piece of property.

\footnotetext{
22 Section 30(2) Trustee Act 1925 allows trustees to reimburse themselves out of the trust for all expenses incurred by the trustees in the "due performance of theur duties and due exercise of their powers": Carver v. Duncan [1985] S.T.C. 356, 363 per Lord Templeman.

23 No right of indemnity can, of course, arise in respect of expenses improperly incurred through unreasonable conduct on the part of the trustee: Re Chapman [1895] L.T. 66.

24 This may, of course, be contrasted with a company in which the directors, acting as agents for the company, do have the power to bind the company, depending upon the terms of their agency, and upon the concept of ratification. Thus outsiders in a company context, unlike the third parties to a trust, certainly will need to be interested in the extent of a director's powers. Accordingly the two issues of release and validation are relevant in a company context, though, as stated above, these two concepts tend to be combined within the single word "ratification".

25 See Gower, Chapters $2 \& 3$.

26 Those acting for the members had two distinct functions: holding the property as trustees and contracting for the company as agents. These two functions could be caried out by two distinct groups: Sealy, op. cit., p. 84.

27 Whilst it was possible for directors to fulfil both the role of trustee and agent, it was actually relatively uncommon for this to occur.

28 Sealy, op. cit., at p. 89.
} 


\section{Separate legal personality}

In a modern company there are, of course, not two groups involved in the equation but three. ${ }^{29}$ Unlike the deed of settlement companies, the modern company is an entity separate to the shareholders ${ }^{30}$ and the directors primarily act for the company. ${ }^{31}$ The directors accordingly owe their duties to the company alone, ${ }^{32}$ unless they have acted in such a way as to put themselves into the situation of owing duties direct to the shareholders. ${ }^{33}$

Since the company cannot act on its own behalf, representatives need to act for it in order to determine when a wrong done (or about to be done) to the company should be ratified. Those representatives are the shareholders of the company ${ }^{34}$ although it has been suggested by some commentators ${ }^{35}$ and by some judges ${ }^{36}$ that, at least in some situations, the appropriate organ of the company to ratify a wrong done to the company by the directors is the board. These arguments rest in part on a view of ratification as a decision-taking process, and suggest that to allow the shareholders to take part in this decision-taking process is to deprive the board of the managerial powers which are conferred upon it by most articles of association. ${ }^{37}$ Whilst this may be correct in a limited contractual context, for example as regards individual directors acting in excess of the contractual powers which have been conferred upon them by the board in which case the board is clearly competent to "ratify", in the area of fiduciary duties, this is not an accurate view of the situation. Ratification of fiduciary duties is not a decision-taking process as such, but a process of combined "release" (of directors from their personal wrongdoing) and affirmation (of the wrong done) and accordingly it poses no threat to the managerial powers of the

29 Or more if the interests of creditors, employees and others, discussed below at notes 39-41, are taken into account.

30 Salomon v. Salomon \& Co. Ltd. [1897] A.C. 22.

31 In addition, of course, a director of a modern company cannot to be regarded as in any way an owner of property belonging to his principal.

32 Percival v. Wright [1902] 2 Ch. 421.

33 Breiss v. Woolley [1954] A.C. 333; Allen v. Hyatt (1914) 30 T.L.R. 444; Coleman v. Myers [1977] 2 N.Z.L.R. 225 where Woodhouse J. said it would depend "upon all the surrounding circumstances and the nature of the responsibility which in a real and practical sense the director has assumed towards the shareholder" (p. 324), a view adopted by Browne-Wilkinson V.-C. in Re Chez Nico (Restaurants) Ltd. [1991] B.C.C. $736,750$.

34 Regal (Hastings) Ltd v. Gulliver [1967] 2 A.C. 134n, 150 per Lord Russell. cf., where the company is insolvent or on the verge of insolvency, in which case it has been suggested that the interests of the creditors will intervene and the shareholders are not then the correct medium of ratification.

35 E.g. L. S. Sealy, "The Director as Trustee" [1967] C.L.J. 83, 102, although Professor Sealy discounts ultra vires acts from his analysis, believing that these can be ratified by shareholders without offending the managerial principle.

36 E.g. Breckland Group Holding Ltd. v. London and Southwark Properties Ltd. [1989] B.C.L.C. 100 per Harman J.; Queensland Mines Ltd. v. Hudson (1978) 52 A.L.J.R. 399 (P.C.), although in Queensland, since the only two shareholders of the company were themselves companies in which the two directors played leading parts, the Privy Council may have treated the approval of the board as equivalent to that of the shareholders' nominees.

37 See, e.g., Table A Companies Act 1985, A. 70. 
board. The position of shareholders as the ratifiers of wrongs done to the company should not be doubted on this basis. ${ }^{38}$

The question arises as to whether shareholders are necessarily the best representatives of the company in this matter. If, as it seems clear, a director's duties today are properly owed to the company should those duties be regarded, in this context, as being owed in some way to the shareholders so that they can ratify breaches of those duties? The idea that the shareholders collectively constitute the company has not been valid for some time, and the identification of shareholders with the company must further be doubted by the increasing judicial and statutory recognition of other interest groups, principally creditors ${ }^{39}$ and employees. ${ }^{40}$ There is even a suggestion that the interests of the public at large could be added to this picture. ${ }^{41}$ The identification of the present shareholders with the company was never an accurate analysis of a modern company, and that view seems to be getting less tenable all the time.

There are other difficulties with regarding duties owed to the company as actually being owed to the shareholders in this way. As a matter of policy, questions can be asked about the appropriateness of shareholders to represent the company. The shareholders, whilst being asked to act on behalf of the company in this regard, are in a peculiar position in relation to the company which may make it almost impossible for them to remain impassive or wholly independent when deciding whether or not to ratify a wrong done to the company. There are two principal reasons for this. Firstly, the shareholders will have money invested in the company and so the decision to ratify (or not) the directors' wrongdoing will often have an economic impact on them. This may often be supposed to sharpen their concern to protect the company since if the company prospers then, generally speaking, the shareholders will also prosper. However, there may well be circumstances in which their economic interests conflict with those of the company, where, for example, the directors have wrongfully paid a dividend to the shareholders out of the capital of the company. Secondly, the

38 This is obviously subject to the ability of the shareholders to insert a provision into the articles of the company which authorises the directors to ratify in such circumstances.

39 The interests of creditors in the well being of the company, at least as regards a company which is insolvent or is nearing in solvency, have been recognised by the courts (Winkworth v. Baron Developments [1986] 1 W.L.R. 1512 and see D. Prentice, "Creditors' Interests and Directors' Duties” 10 O.J.L.S. 265) to the extent that doubt has been cast on the ability of shareholders to continue to ratify directors' wrongdoing in such circumstances.

40 Companies Act 1985, s. 309 states that directors are to have regard to the "interests of the company's employees in general, as well as the interests of its members" though this duty remains enforceable only by the shareholders and is merely permissive in nature: Re Welfab Engineers Ltd. [1990] B.C.L.C. 833. It may be noted that, in comparison to the position of creditors, at least at the time of insolvency, that it "seems to be assumed that the statutory recognition of the employed has not affected the power of the shareholders to ratify breaches of duty, though it is not clear why this should be the case where the breach consists of a failure to consider the interests of the employees": Gower, p. 645 fn. 71.

41 "Modern Company Law for a Competitive Economy" (DTI, London, February 1999) discusses whether directors should take account of other interests, including those of employees, creditors, customers, the environment, and the wider community :chapter 5.1. 
shareholders may also be the wrongdoing directors. In a way which is impossible in the trust analogy (a sole trustee cannot also be a sole beneficiary), the wrongdoers may be given the opportunity to use their shares to validate their own wrongdoing to a third party (the company). ${ }^{42}$

\section{Majority rule}

The fundamental principle by which decisions in a company are taken is that of majority rule. ${ }^{43}$ This means that "[u]nless some provision to the contrary is to be found in the charter or other instrument by which the company is incorporated, the resolution of the shareholders, duly convened, upon any question with which the company is legally competent to deal, is binding upon the minority, and consequently upon the company". ${ }^{44}$

Of course, the reason for such a principle is clear. To require unanimity for all of the shareholders' decisions would make the process of decisionmaking impractical and unworkable. In most circumstances, a decision by a bare majority of the shareholders will bind the rest, and will, of course, bind the company. Where the decision is one which is more fundamental or important it is open to parliament ${ }^{45}$ or to the shareholders themselves ${ }^{46}$ to require the decision to be taken by a higher percentage of the shareholders. Whereas unanimity has obtained some acceptance as a method of taking a decision ${ }^{47}$ it is largely utilised as a method of taking decisions, which would otherwise be decided by a bare majority, in a more informal manner.

The concept of majority control is closely associated with the non-interventionist attitude of the courts in company matters ${ }^{48}$ so that the courts will generally not interfere with company law matters which are under the control of the majority because "if the thing complained of is a thing which in substance the majority of the company are entitled to do regularly ... there can be no use in having a litigation about it, the ultimate end of which is only that a meeting has to be called, and then ultimately the majority gets its wishes." 49

The situation can, of course, be contrasted with the trust situation in which the beneficiaries can only bind themselves when giving a release to the trustees. ${ }^{50}$ Each person to whom a duty is owed has a personal right to release the wrongdoer from that duty. To be free from doubt a trustee

\footnotetext{
42 North-West Transportation Co. Ltd v. Beatty (1887) 12 App. Cas. 589.

43 This principle has been recognised for over 250 years: $R$ v. Varlo (1775) 1 Cowp. 248; Att. -Gen. v. Davy (1741) 2 Atk. 212.

44 North-West Transportation Co. Ltd v. Beatty (1887) 12 App. Cas. 589, 593 per Sir Richard Baggallay.

45 E.g., Companies Act 1985, s.9 which requires a special resolution for the alteration of a company's articles.

46 For example, by a provision in the company's articles, or by way of a shareholders' agreement.

47 Re Duomatic [1969] 2 Ch. 365; Cane v. Jones [1980] 1 W.L.R. 1451

48 K. Wedderburn, "Shareholders' Rights and the rule in Foss v. Harbottle" [1957] C.L.J. 194, 197 et seq.

49 MacDougall v. Gardiner (No. 2) (1875) 1 Ch. D. 13, 25 per Mellish L.J.

50 See note 20 above.
} 
therefore needs to obtain the unanimous consent of all the relevant beneficiaires. In a modern company there is no room for a "personal" right of this kind, so that a bare majority of a group other than that to which the duty is owed can decide whether to validate that wrongdoing.

\section{A vote as a piece of property}

The idea that shareholders hold their votes as a piece of property is well embedded in company law. In North-West Transportation v. Beatty ${ }^{51}$ a company sought to obtain a ship from one of its directors for $£ 125,000$. This transaction was put to the shareholders in general meeting for approval and passed by way of a majority vote even though the director in question also voted his shares in favour of the resolution, and without his votes the resolution would not have been passed. The minority wanted the ship purchase to be set aside. The Privy Council held that the resolution approving the purchase was valid: " $[\mathrm{t}]$ he general principles applicable to cases of this kind are well established ... every shareholder has a perfect right to vote upon any such question, although he may have a personal interest in the subject matter opposed to, or different from, the general or particular interests of the company." 52

The shareholders of a company therefore generally ${ }^{53}$ owe no fiduciary duties to one another. It is clear that on the basis of this principle a shareholder may ratify a wrong which he committed in another capacity, such as a breach of duty as a director, and he may do so even if he is a controlling shareholder of the company, subject, of course, to the discussion below about unratifiable wrongs.

Of course, the beneficiaries of a trust can also utilise the decision of whether or not to release the trustees as they see fit, without any need to refer to the interests of anyone else. In that way their decision to release is as much a right of property as a shareholders' right to vote. However, crucially, a beneficiary can only bind him or herself with the decision whether to release the trustees. The beneficiary's decision will not bind anyone else, whereas the principle of majority control means that a shareholder, acting in its own self interest, in exercising its right to vote, can affect other shareholders.

\section{REASSESSING RATIFICATION}

The original trust concept of release as one in which those to whom a duty is owed have a personal right to release those who owe them a duty, has been translated, in a modern company, to a wholly different concept. The company law translation allows a bare majority of a group other than that to which the duty is owed (which group may include those with divergent

51 (1887) 12 App. Cas. 589.

52 Ibid., at p. 593 per Sir Richard Baggallay.

53 The most obvious exception is, of course, in regard to the alteration of a company's articles, where some constraints are imposed upon the voting of the shareholders. 
interests or even the wrongdoers themselves) to decide whether or not to validate a wrong done to a third party (the company) and in doing so allows that majority to act in its own best interests, rather than those of the company.

In this situation it might have been expected that some protection for the company against its potentially self-interested representatives might have been built into the ratification process. That protection could take a number of forms, for example: the manner in which shareholders are allowed to vote on the company's behalf could be constrained in some way; the vote could be taken only by those who could not be regarded as self-interested; the shareholders could be prevented from representing the company in some situations; or the principle of majority rule could be displaced in some circumstances and a higher percentage (possibly 100 per cent) of the shareholders be required to vote in order to ratify a wrong done to the company.

These four examples can be regarded as falling broadly into two kinds: constraints based on the nature of the transaction and constraints based on the nature of the voting by the shareholders. The first requires the court to determine whether the transaction is of the sort where protection of the company from the shareholders is necessary, for example, if it is clear from the nature of the transaction itself that the company's interests are being suborned to the interests of the shareholders. If the answer is yes, then no enquiry is then made as to whether the votes of the shareholders actually demonstrate such self-interest on the part of some or all of them. The second requires the court to investigate the way in which the shareholders actually use their votes.

A similar distinction was drawn by Vinelott J. in Prudential Assurance Co. Ltd v. Newman Industries (No. 2). ${ }^{54}$ This case involved a complex set of facts, revolving around one company, TPG, of which B and L were senior directors. A company $\mathrm{S}$ (of which B and L held all of the shares) was a substantial shareholder in TPG, whilst TPG in turn held a substantial, though not a majority, stake in another company, N. B and L arranged for $\mathrm{S}$ to sell its main assets to $\mathrm{N}$ at a gross over-valuation. The consent of N's shareholders was obtained, though by a "misleading and tricky" circular. This was an action by a minority shareholder in $\mathrm{N}$ for damages against $\mathrm{B}$, $\mathrm{L}$ and TPG.

\footnotetext{
54 [1980] 2 All E.R. 841. This case did, of course, go to the Court of Appeal where Vinelott J's decision was affirmed only in part: [1982] Ch. 204. Vinelott J. drew a distinction between the transaction (wrong done to the company) and the exercise of the shareholders' votes to ratify that wrong (wrong done to the other shareholders). To the extent that the shareholders are representing the company, and therefore the wrong done to them is in fact a wrong done to the company, this is an acceptable distinction to draw, even if Vinelott J. was wrong to believe that this did represent the position of the law at the time. Both of the constraints which will be discussed here refer to the relationship between the company and the shareholders: either the transaction puts the company at risk from the shareholders and constraints should be imposed (transaction-based constraints) or the manner of the voting demonstrates this risk and constraints should be imposed (voting-based constraints). In either case the constraints are being imposed to protect the company, represented ultimately by the minority shareholders, not to protect the shareholders per se.
} 
Vinelott J. took the novel view that, contrary to all previous authority on the point, all wrongdoing by directors is capable of ratification, but that it may be "unconscionable" for the majority to use their voting power in general meeting to prevent an action being brought against the wrongdoers. According to Vinelott $J$. the fraud lies in the use of their voting power, not in the character of the act or the transaction giving rise to the cause of action. He stated that " $\ldots$ there is no obvious limit to the power of the majority to authorise or ratify any act or transaction whatever its character, provided it is not ultra vires or illegal and that the majority does not have an interest which conflicts with that of the company." ${ }^{55}$ In assessing the majority's votes, the court should disregard votes cast or capable of being cast by shareholders who have an interest which conflicts with that of the company. ${ }^{56}$ This principle has been heavily criticised by academics. ${ }^{57}$ The Court of Appeal in Prudential ${ }^{58}$ did not actually need to decide the scope of the exception to Foss v. Harbottle and therefore declined to comment on the substance of Vinelott J.'s analysis..$^{59}$

With these ideas in mind, the next step in the re-examination of ratification involves a consideration of three issues. First, what is the doctrine of ratification as it is currently understood and applied by the English courts, and, in particular, what, if any, protection for the company does this doctrine provide? Second, is the doctrine of ratification synonymous with a decision taken by the shareholders not to sue for a wrong done to the company? Thirdly, if, as it will be argued, the current doctrine of ratification is inadequate to protect the company from its potentially self-interested representatives, what limits should be placed on the ability of shareholders to ratify wrongs on the company's behalf?

\section{What is ratification?}

English law has always recognised a category of non-ratifiable wrongs. Many of these instances of non-ratifiability can be explained on the basis that the shareholders cannot ratify the wrong done to the company, either because the wrong is not done to the company (and the company is not,

\footnotetext{
55 Ibid., at p. 862.

56 This obviously conflicts with earlier caselaw on this point, e.g. Mason v. Harris (1879) 11 Ch. 97, 109 per James L.J.

57 See, for example, K. Wedderburn, "Derivative Actions and Foss v. Harbottle" (1981) 44 M.L.R. 202; L. S. Sealy, "Foss v. Harbottle-A Marathon where Nobody wins" [1981] C.L.J. 29, 32. For approval of this principle see, for example, S.M. Beck, "The Saga of Peso Silver Mines: Corporate Opportunities Reconsidered" (1971) 49 Can B. Rev. 80; R. Baxt, "Judges in their own cause: The Ratification of Directors' breaches of duty" (1978) 5 Monash U.L. Rev. 16, 49; G.R. Sullivan, "Restating the Scope of the Derivative Action" [1985] C.L.J. 236, 245.

58 [1982] Ch. 204

59 Beyond saying (at pp. 221-222) firstly that there was no exception to Foss v. Harbottle simply where justice requires it, as suggested by Vinelott J., and, secondly, that Vinelott J. should have decided whether the plaintiffs were entitled to sue on behalf of Newman as a preliminary issue.
} 
therefore, the proper plaintiff ${ }^{60}$ or because the company itself is not "legally competent" to deal with the question, ${ }^{61}$ and therefore it is not possible for the shareholders to ratify the act on the company's behalf..$^{62}$ Once these categories are dispensed with, the "real" instances of non-ratifiability, that is where the shareholders could ratify, but are prevented from doing so by the courts, can be dealt with.

It must be said that this is an area of company law which has produced a great deal of confusion, and an equally large volume of academic discussion. ${ }^{63}$ One thing which is, however, clear is the fact that it is the nature of the transaction and not the nature of the voting by the shareholders which is currently relevant in English law. The "fraud" referred to in the "fraud on the minority" exception ${ }^{64}$ refers to the initial transaction, and not whether the wrongdoing directors, in exercising their votes as shareholders actually acted fraudulently in putting their own interests before the interests of the company. The court does not engage in an analysis of the actual motivation behind the voting of the shareholders. ${ }^{65}$

Criticisms can be made of this transaction-based approach. Firstly, the basis of this test remains unclear, despite its relative longevity, as evidenced by the sheer volume of academic writings ${ }^{66}$ which aim to reconcile cases such as Cook v. Deeks ${ }^{67}$ and Regal (Hastings) Ltd. v. Gulliver. ${ }^{68}$ Problems surround what is meant by "corporate property", ${ }^{69}$ by "fraud on the minority", whether bona fides on the part of the wrongdoers will make a difference, and if so how that concept is to be tested and applied. Confusion seems to be rife in this area of the law, indeed, as

60 This is the case where the wrong is done to the shareholders of the company in their personal capacity, for example a breach of the section 14 contract: Hickman v. Kent or Romney Sheep Breeders, Association [1915] 1 Ch. 881; K. Wedderburn, "Shareholders' rights and the Rule in Foss v. Harbottle" [1957] C.L.J. 194 and [1958] C.L.J. 93.

61 North-West Transportation Co. Ltd v. Beatty (1887) 12 App. Cas. 589, 593 per Sir Richard Baggallay.

62 The obvious examples of this are illegality, e.g. the provision of financial assistance by the company in contravention of Companies Act 1985, ss. 151-155, and, prior to the Companies Act 1989, ultra vires. See K. Wedderburn, "Shareholders' rights and the Rule in Foss v. Harbottle" [1957] C.L.J. 194 and [1958] C.L.J. 93.

${ }^{63}$ Gower goes as far as to say that "it is impossible to reconcile all the decided cases with any simple set of propositions": Gower, p. 670.

64 Foss v. Harbottle. (1843) 2 Hare 461.

65 Other than by following the analysis laid down by Vinelott J. in Prudential Assurance Co. Ltd. v. Newman Industries (No. 2) [1980] 2 All E.R. 841.

66 K. Wedderburn, "Shareholders' rights and the Rule in Foss v. Harbottle" [1957] C.L.J. 194 and [1958] C.L.J. 93; B. Rider, "Amiable Lunatics and the Rule in Foss v. Harbottle" [1978] C.L.J. 270; S. Beck, "The Shareholders Derivative Action" (1974) 52 Can. B.Rev. 159; S. Beck, "The Quickening of the Fiduciary Obligation" (1975) 53 Can. B.R. 771; B.H. McPherson, "Duties of Directors and the powers of shareholders" (1977) 51 Aust. L.J. 460; S. Beck, "The Saga of Peso Silver Mines: Corporate Opportunities Reconsidered" (1971) 49 Can. B. Rev. 80.

67 [1916] 1 A. C. 554.

68 [1967] 2 A. C. 134 n.

69 The lack of clarity surrounding the concept of "company property", for instance, seems to spring from the judgment of Lord Davey in Burland v. Earle [1902] A. C. 83, 93, in which he stated that company property included "money, property or advantages which belong to the company or in which the other shareholders are entitled to participate" (emphasis added), leading to the arguments regarding the misappropriation of corporate opportunities. 
Lord Wedderburn stated in 1958, "[i]n the face of the jangle of discordant cases, the law can hardly be regarded as settled". ${ }^{70}$ That statement remains equally true today.

The current approach to ratification is not working correctly if those who seek to make use of it cannot with any certainty define its precise extent and applicability. Of course, it could be argued that ratification is always going to be a difficult issue, particularly in the realm of company law where the court's non-interventionist approach to "internal" company disputes is well known. However, a transaction-based approach seems to exacerbate some, at least, of these difficulties. If derivative actions concern "not so much a fraud on the minority as a fraud on the company" 71 and the minority is "suing to protect, as it were, the company from the unlawful acts of the directors or other wrongdoers" 72 then the issue underlying ratification is the protection of the company from those whose interests are patently contrary to the interests of the company. When the directors are also shareholders, or control the shareholders, then the underlying issue is the protection of the company from the shareholders where those shareholders are acting in their own interests rather than those of the company. If this is the case, then surely it is more direct to approach the issue by determining, as far as possible, whether the shareholders are actually acting contrary to the interests of the company, rather than by attempting to extrapolate information from the circumstances surrounding the wrongdoing.

\section{Is Ratification Synonymous with the Decision Not to Sue?}

Ratification $^{73}$ and the question of whether a derivative action can be brought in relation to the wrongdoing are often treated as being the same issue: "... where the alleged wrong [done to the company] is a transaction which might be made binding on the company or association of persons and all its members by a simple majority of the members, no individual member of the company is allowed to maintain an action in respect of that matter..."74 and Megarry V.-C. in Estmanco v. G.L.C. stated that the "guiding principle underlying Foss v. Harbottle may come to be whether an ordinary resolution of the shareholders could validly carry out or ratify the act in question". ${ }^{75}$ As a result the fraud on the minority exception to Foss

\footnotetext{
K. Wedderburn, "Shareholders' rights and the Rule in Foss v. Harbottle" [1958] C.L.J. 93, 105.

1 Ibid., at p. 95.

72 Ferguson v. Wilson (1866) 2 Ch. App. 77, 90 per Cairns L.J.

3 In this situation the courts are of the view that it is ratifiability rather than ratification per se. which is relevant: Hogg v. Cramphorn Ltd. [1967] Ch. 254, cf. Vinelott J. in Prudential Assurance Co. Ltd. v. Newman Industries (No. 2) [1980] 2 All E.R. 841. In view of these cases the term "ratification" in this section should therefore be interpreted as including a situation in which ratification is possible but has not actually occurred.

74 Edwards v. Halliwell [1950] 2 All E.R. 1064, 1066 per Jenkins L.J.

75 [1982] 1 W.L.R. 2, 11.
} 
v. Harbottle ${ }^{76}$ the "only true exception" to the principle set out in that case, ${ }^{77}$ has been treated as being exactly the same as the content of the category of the "real" instances of non-ratifiability.

This view was doubted in Smith v. Croft (No. 2) 78 in which the plaintiff shareholders brought an action against the directors alleging that the directors had acted ultra vires by, amongst other things, paying themselves excessive salaries and acting in breach of the financial assistance rules. ${ }^{79}$ Knox J. held that, in relation to the ultra vires actions which, at that time, were unratifiable, ${ }^{80}$ there could nevertheless be a valid decision taken not to go ahead with the action against the wrongdoing directors on the company's behalf if that decision was taken by an "appropriate independent organ". ${ }^{81}$ In other words, Knox J. suggested that even in circumstances in which the act is unratifiable the decision not to sue can nevertheless be validly taken by an independent body of the shareholders. ${ }^{82}$ According to Knox J., therefore, ratifiability and the ability of minority shareholders to bring an action are not wedded together. Whether an action is ratifiable or not, an independent body of shareholders can always decide that no action can be brought on behalf of the company, effectively blocking a derivative action. By "independent" he meant that the decision of the shareholders should be made for the company's benefit, not for the improper purpose of protecting the wrongdoers or that, at least, there should be no substantial risk that this would occur. ${ }^{83}$

A distinction between two different situations needs to drawn here. The first situation is that in which a valid ratification occurs. Can that be regarded as equivalent to a decision not to sue, i.e. can a valid decision to sue be taken later by the shareholders in relation to that ratified wrong? The second situation is that in which no decision to sue has been taken by the shareholders. Can that decision not to sue be deemed to be equivalent to a ratification?

In the first situation, there are good reasons for regarding ratification as equivalent to the decision not to sue. ${ }^{84}$ The two issues are two sides of the

\footnotetext{
76 (1843) 2 Hare 461.

77 Law Commission report. This is because only in the "fraud on the minority" exception can a wrong be identified in relation to which the individual may sue derivatively even though the shareholders could ratify.

78 [1988] Ch. 114.

79 Then Companies Act 1981, s. 42, now Companies Act 1985, ss. 151-152.

80 See, now, Companies Act 1985, s. 35 (as amended) which provides that a third party who is not an insider (see section 322A) can rely on an ultra vires act as against the company whether or not it has been ratified, and that the company can enforce against the third party provided the action has been ratified by a special majority.

${ }^{81}$ [1988] Ch. 114, 189.

82 Knox J.'s judgment goes further and leaves open the possibility that the "independent organ" of the company "will vary according to the constitution of the company concerned and the identity of the defendants" (pp. 159-160) i.e. it leaves open the possibility that this independent organ could be all, or part of, the board of directors.

83 [1988] Ch. 114, 189

84 Gower, p. 675.
} 
same coin. The decision whether or not to ratify a wrong is no more than an analysis of the seriousness of the wrong, of whether, in effect, it should be "forgiven". Once validly ratified, where is the wrong to the company which will found a subsequent derivative action? However, the validity of the view that valid ratification of an action ensures that no decision to sue will be taken in the future, depends upon whether ratification is binding on future shareholders, in other words whether the ratification extinguishes or merely suspends the shareholders' rights. It seems clear that as regards the shareholders who exist at the time of the valid resolution to ratify the wrong, those shareholders will be estopped from bringing a claim in relation to that wrong in the future, even if they voted against ratification at the time, or did not vote at all, as a result of the principle of majority rule. As regards future shareholders, they will only be prevented from deciding to bring an action on the company's behalf by prior ratification if that ratification extinguishes the shareholders' rights. Put another way, the important issue is whether the decision to ratify will do more than prevent the shareholders at the time of the ratification from taking the decision to sue in the future. Support for this view can be found in a number of company law cases ${ }^{85}$ and it is submitted that the better view is that valid ratification by the shareholders should be regarded as extinguishing their right to sue in the future.

If ratification is extinctive of the shareholders' right to sue, as argued above, can the reverse be said to be true? Can a decision by the shareholders not to sue also have an extinctive effect on the cause of action? If the answer to this question is "yes" then there cannot be said to be any real difference between ratification and the decision not to sue. Unfortunately, there seems to be no authority on this point. However, consider a situation in which a director of a company breaches his or her fiduciary duty to the company and a valid decision is taken by the appropriate organ of the company (whatever that is) not to sue. Later, but before the expiry of the limitation period, the company goes into insolvency and a liquidator is appointed. Can the liquidator then sue the wrongdoing director? There seems to be no good reason in principle why the liquidator should be prevented from doing so. On that basis the decision not to sue and ratification cannot be regarded as being entirely synonymous.

\section{What are the limits of ratification?}

If, as argued, there is much to be said for regarding ratification as a process whereby the voting of the shareholders, rather than the nature of the trans-

\footnotetext{
85 E.g., Salomon v. A. Salomon \& Co. Ltd. [1897] A.C. 22, 57 per Lord Davey; In re Horsey \& Weight Ltd [1982] Ch. 442, 454 per Buckley L.J.; Rolled Steel Ltd v. British Steel Corporation [1986] Ch. 246, 296 per Slade L.J.; Aveling Barford Ltd. v. Perion Ltd. [1989] B.C.L.C. 626, 630-631 per Hoffmann J; Multinational Gas and Petrochemical Co. v. Multinational Gas and Petrochemical Services Ltd. [1983] Ch. 258, 280 per May L.J.; Meridian Global Funds Management Asia Ltd. v. The Securities Commission [1995] 3 All E.R. 918, 923 per Lord Hoffmann.
} 
action is relevant, then obviously a new basis for deciding whether a wrong is or is not ratifiable needs to be determined. If the courts are no longer going to limit the powers of the shareholders to ratify in accordance with issues such as whether the transaction is a "fraud on the minority" then other constraints will need to be found which will limit the ability of the general meeting to ratify anything by a bare majority. There are three potential bases for that process, all of which place constraints of one sort or another on the principle of bare majority rule: (i) all shareholders must vote in favour of ratification; (ii) only the votes of independent shareholders will count in determining ratifiability; or (iii) all shareholders will have their votes counted and shareholders will continue to take decisions by a bare majority but they will be constrained as to how they exercise their votes. Whilst the first of these focuses on the practical issue of extinguishing the shareholders' right to sue on behalf of the company, the second and third focus on the issue of how a court can determine whether ratification is in the best interests of the company.

\section{i. Unanimity}

Whilst a requirement of unanimity amongst shareholders for all decisions would be an unnecessary burden, and majority decision-making is clearly preferable in many circumstances, would a requirement of unanimity amongst the shareholders in some circumstances be an advantage to the company? This could be, for example, where there is some kind of presumption of wrongdoing, such as where the directors have made a gift to themselves of corporate property. ${ }^{86}$

Although majority rule is the norm for ratification by shareholders, the possibility of ratification by unanimity is widely recognised, at least in those circumstances where ratification by ordinary resolution is possible. ${ }^{87}$ The more interesting issue is whether unanimity could be used to cure a wrongdoing which was not otherwise ratifiable. There is some judicial support $^{88}$ for the view that shareholders ought to be able to act unanimously in order to cure anything within their power, unless the company is close to, or actually in, insolvency, ${ }^{89}$ for example, May L.J. in Multinational Gas and Petrochemical Co. v. Multinational Gas and Petrochemical Services $L t d$. said "the unanimous decision of all the shareholders in a solvent com-

${ }^{86}$ E.g., Menier v. Hoopers Telegraph (1874) L.R. 4 Ch.App. 376; Cook v. Deeks [1916] 1 A.C. 554.

87 Re Duomatic [1969] 2 Ch. 365; Cane v. Jones [1980] 1 W.L.R. 1451. For a full discussion of the principle of unanimous informal consent see R. Grantham, "The unanimous consent rule in company law" [1993] C.L.J. 245.

88 Salomon v. A. Salomon \& Co. Ltd. [1897] A.C. 22, 57 per Lord Davey; In re Horsey \& Weight Ltd [1982] Ch. 442, 454 per Buckley L.J.; Rolled Steel Ltd v. British Steel Corporation [1986] Ch. 246, 296 per Slade L.J.; Aveling Barford Ltd. v. Perion Ltd. [1989] B.C.L.C. 626, 630-631 per Hoffmann J.

89 At this point, of course, the interests of the creditors will intervene: Winkworth v. Edward Baron Development Co. Ltd. [1987] B.C.L.C. 193. 
pany about anything that the company under its memorandum of association has power to do shall be the decision of the company", ${ }^{90}$ a view which recently found support, albeit obiter, in Lord Hoffmann's judgment in Meridian Global Funds Management Asia Ltd. v. The Securities Commission. ${ }^{91}$ This principle can be criticised since it seems based on the now rather old-fashioned view of the shareholders actually comprising the company. ${ }^{92}$ However, if the decision is within the power of the shareholders, so that they are not usurping the powers of the directors, ${ }^{93}$ and the company is not insolvent, so that the interests of creditors need not be considered, are there any good reasons for preventing the shareholders from ratifying in this way? In particular, would allowing the shareholders to ratify in this way be prejudicial to the interests of the company? Within this limited context it might be asked what the company's interests actually comprise. "The company" for these purposes is likely to consist primarily of the present and future shareholders and it might be more practicable to ask, therefore, whether ratification by unanimity might prejudice the interests of these individuals.

Of course, if all of the shareholders are wrongdoers and are able to vote in favour of ratification of their own wrongdoing it is difficult to see that any prejudice to the present shareholders actually occurs. If only some of the shareholders are wrongdoers then presumably the others can take a decision not to ratify. If they do not then their interests and the interests of future shareholders are protected but if ratification does occur then that protection will be lost, whether that ratification was in "the company's" best interests or not. ${ }^{94}$ If a valid ratification has occurred by a unanimous decision of the shareholders (whether wrongdoers or not) then, as has already been seen, ${ }^{95}$ the present shareholders will lose their right to take a decision to sue on the company's behalf in relation to that wrongdoing, but it is difficult to see how this could cause prejudice to those present shareholders who have taken the decision. The danger of allowing ratification by unanimity is that the present shareholders will also bind future shareholders, ${ }^{96}$ who may be independent of the wrongdoers and may well have a quite different view of the wrongdoing. If the aim of ratification is ulti-

\footnotetext{
90 [1983] Ch. 258, 280.

1 [1995] 3 All E.R. 918, 923.

92 R. Grantham, "The unanimous consent rule in company law" [1993] C.L.J. 245.

93 The cases in which shareholders appear to be able to take valid decisions concerning matters which are properly within the directors' sphere of competence, e.g. Re Fletcher Hunt (Bristol) Ltd. [1989] B.C.L.C. 108, merely by acting unanimously do not sit well with cases such as Automatic SelfCleansing Filter Syndicate Co. Ltd. v. Cunninghame [1906] 2 Ch. 42 which regard the spheres of authority of the directors and the shareholders as being quite separate and should be regarded with caution: R. Grantham "The unanimous consent rule in company law" [1993] C.L.J. 245.

94 Whilst it is hoped that shareholders who are not wrongdoers would vote in the company's best interests, this cannot be guaranteed: North-West Transportation v. Beatty (1887) 12 App. Cas. 589.

95 See note 85 above, and associated text.

96 If a valid ratification is extinctive of the shareholders' right to sue in the future, see note 85 above and associated text.
} 
mately the protection of the company (here represented by the future shareholders), then a requirement of unanimity where there is a presumption of wrongdoing would not necessarily ensure that protection.

Finally, any rule requiring unanimity would have to face a difficult practical issue: in anything other than the very smallest company, would a requirement of unanimity be possible?

\section{ii. Independent Shareholders}

Another possibility would be to create an independent body, separate to the company, its directors or its shareholders, in order to determine whether a wrong done to the company should be ratified, the advantage being that such an independent body could be presumed to take the decision on the company's behalf and in the company's interests, without the distraction of its own interests and expectations. However, in the context of a modern company, no such group exists. Short of completely restructuring company law in order to add such a watchdog, the next best option is to attempt to limit the ability to ratify a transaction to those shareholders who can be regarded as independent.

The English courts have generally maintained that they cannot submit an issue to a meeting at which only disinterested shareholders can vote. ${ }^{97}$ However, Vinelott J. in Prudential v. Newman (No. 2) suggested something like this when he stated that, in his opinion, “... there is no obvious limit to the power of the majority to authorise or ratify any transaction whatever its character, provided that it is not ultra vires or unlawful and that the majority does not have an interest which conflicts with that of the company" 98 and that "in ascertaining the view of the majority whether it is in the interests of the company that the claim be pursued, the court will disregard votes cast or capable of being cast by shareholders who have an interest which conflicts with the interests of the company." 99 Although this view has been criticised, ${ }^{100}$ the idea of ratification by an independent, disinterested, group of shareholders, was picked up by Knox J. in Smith v. Croft (No. 2). ${ }^{101}$ In that case, "independence" again meant that the decision had been taken for the company's benefit, not for the purpose of protecting the wrongdoers, or that at least there should not be a substantial risk of that occurring.

\footnotetext{
97 Mason v. Harris (1879) 11 Ch. D. 97, 109 per James L.J.

98 [1980] 2 All E.R. 841, 862.

99 Ibid., at p. 874 (emphasis added).

100 See, e.g., K. Wedderburn, "Derivative actions and Foss v. Harbottle" (1981) 4444 M.L.R. 202, 208; L. S. Sealy, "Foss v. Harbottle-A Marathon where Nobody wins" [1981] C.L.J. 29, 32. For approval of this principle see, for example, S.M. Beck, "The Saga of Peso Silver Mines: Corporate Opportunities Reconsidered" (1971) 49 Can B. Rev. 80; R. Baxt, "Judges in their own cause: The Ratification of Directors' breaches of duty" (1978) 5 Monash U.L. Rev. 16, 49; G.R. Sullivan, "Restating the Scope of the Derivative Action" [1985] C.L.J. 236, 245.

101 [1988] Ch. 114 and see D. Prentice, "Shareholder action: the rule in Foss v. Harbottle" (1988) 104 L.Q.R. 341 .
} 
It needs to be recognised that what both Vinelott J. and Knox J. are suggesting is a process whereby the disinterested votes of "independent" shareholders are taken into account in order to "ascertain whether it is in the interests of the company that the claim is pursued". ${ }^{102}$ The courts are looking for evidence of what is in the best interests of the company, rather than undertaking a process of disenfranchisement. No shareholders are prevented from voting, but those shareholders who are interested will find that their votes are not taken into account when the court decides whether ratification should be allowed. A more radical step would be for the courts to get involved at an earlier stage and actually disenfranchise those shareholders which it regards as interested. However, this would involve the court in a much more interventionist role for very little gain. It seems likely that just as much can potentially be achieved by the court undertaking this investigation after the vote has been taken, as suggested by Vinelott J. and Knox J.

The idea of some kind of independent group whose votes are used to ascertain ratifiability has some attractions, but also raises a number of potential practical difficulties. ${ }^{103}$ Firstly, how is that independence to be tested? There may well be substantial practical difficulties with the courts discovering whether or not shareholders are actually "interested" in a particular vote. ${ }^{104}$ The links within a company are often more complex than might be supposed. ${ }^{105}$ Even if the wrongdoers are discounted, how is it to be ascertained that there is no "substantial risk"106 that their colleagues, who may have worked with them for many years in a small company, may be close friends or even family, will not vote otherwise than for the benefit of the company?

In addition, the courts would need to decide just what is meant by independence and how its presence is to be detected. There are two obvious tests of disinterest on the part of shareholders. Firstly, the court could try to determine those shareholders who, in general terms, it regards as "interested" and then only allow the votes of the other, disinterested, shareholders, to determine the ratification of the wrongdoing, however those shareholders actually vote in practice. Secondly, the court could investigate the

102 [1980] 2 All E.R. 841, 874 per Vinelott J.

103 However, in one Australian case, Biala Property Ltd. v. Mallina Holdings Ltd. (No. 2) (1993) 11 A.C.S.R. 785, the court was prepared to undertake a detailed examination of how major shareholders acquired their shares, and to find that a number of apparently independent shareholders were not, in fact, as disinterested as they appeared. In Australia the Companies and Securities Law Review Committee has recommended that interested directors, their associates and relatives, should not be able to vote on a decision to relieve that director from liability for wrongdoing: Company Directors and Officers: Indemnification, Relief and Insurance, Report No. 10, May 1990, para. 60.

104 In particular, the share register in England does not reflect the beneficial interests which exist in shares. Company law has generally allowed that beneficial holder to remain well hidden, so that, for example, there is no duty on a company to take account of such interests, even if they are known to the company: Re Perkins, ex p. Mexican State Barbara Mining Co. (1890) 24 Q.B.D. 613 as codified in s. 360 Companies Act 1985.

105 As the Australian courts found in the Biala case; see note 103, above.

106 Smith v. Croft (No. 2) [1988] Ch. 114, 189 per Knox J. 
way in which each individual shareholder actually exercises his or her vote and then discount those votes which the court determines were not exercised in a disinterested manner, however that disinterest is to be measured. Vinelott J. in Prudential v. Newman (No. 2) adopted the first of these tests, simply requiring the court to undertake an analysis of those shareholders whose interests conflict with the company and then to disregard their votes when determining ratifiability. This test is subject to all of the practical difficulties set out above, but at least retains a measure of objectivity in the court's analysis. The second approach is more difficult, because it requires the court to delve into the murky world of the shareholders' intentions, albeit that only a "substantial risk" of a conflict of interest is required. Knox J. in Smith v. Croft (No. 2) seems to adopt this second approach, as he is concerned with whether the decision has actually been taken for the company's benefit. Whichever test is followed, however, the difficulties in asking the court to undertake one or other of these analyses are clear.

The second principal difficulty relates to the possibility that, after going through whichever test is utilised to ascertain independence, none of the shareholders can be regarded as being independent. Who is then able to take the decision to ratify? If no one, then the wrongdoing becomes unratifiable and the decision to bring a derivative action on the company's behalf cannot be blocked. If all the shareholders are wrongdoers then they presumably would not wish to bring such an action anyway, but it may, again, have important ramifications for future, potentially untainted, shareholders.

It may also be said that any constraint based on the idea that only the votes of disinterested shareholders would be counted when determining the issue of ratification would be contrary to the dicta of Lord Russell in Regal (Hastings) Ltd. v. Gulliver that the directors could "have protected themselves by a resolution (either antecedent or subsequent) of the Regal shareholders in general meeting." 107 No reference is made to the interested directors' shares being discounted for the purposes of determining ratification, indeed quite the reverse since the fact that the directors between them held a majority of the shares was taken as evidence that a valid ratifying resolution could be passed by the shareholders. Vinelott J. did not deal with this difficulty satisfactorily in Prudential ${ }^{108}$ and this dicta therefore remains a hurdle for the introduction of a disinterested shareholders test.

\section{iii. Voting Constraints}

A third way to try to ensure that the shareholders are not infected by their own concerns when voting on behalf of the company would be to require that any vote taken on behalf of the company was conducted in a manner 
calculated to ensure that the company's concerns remained uppermost, the most obvious being a requirement that any vote be exercised in the company's best interests.

To the extent that any voting constraint imposed by the court seeks to discover the individual motivations of each shareholder in exercising his or her vote, for example, by asking whether a particular shareholder actually exercised that vote in the company's best interests or, rather, in their own interests, then this method of constraint is extremely similar to that set out above in relation to independent shareholders. These two methods of constraint are not entirely identical, however, particularly where the interest of the shareholders in the above test is ascertained by some general means external to the method of their voting, as suggested by Vinelott J. They do both obviously attempt to ascertain whether ratification would be in the best interests of the company, but in the "disinterested shareholder" test, interested shareholders would be allowed to vote as they wished, but their votes would be discounted by the court when determining whether ratification was in the company's best interests whereas under this heading all shareholders would vote and have their votes counted but would be constrained to vote in a particular manner. Both constraints offend the principle of a vote as a piece of property, as laid down in North-West Transportation v. Beatty, ${ }^{109}$ and both share the practical difficulties in their operation which have already been discussed.

The alternative to investigating the voting intentions of each individual shareholder is to look at the shareholders' decision on a more global scale in order to determine whether the ratification on the company's behalf should be regarded as valid. The court could look at the shareholders' decision as a whole in order to determine whether it was in the best interests of the company. The courts could preserve their largely non-interventionist position by requiring the principle of majority rule to be upheld unless it could be said that no reasonable person could regard the decision taken by the shareholders to be in the best interests of the company. ${ }^{110}$

There is, of course, one area of company law in which this type of constraint is already imposed by the courts: when shareholders vote to alter the articles of the company by special resolution ${ }^{111}$ they must exercise that vote "bona fide in the best interests of the company". ${ }^{112}$ Of course, the application of this "best interests" test has been criticised in the context of the alteration of a company's articles, particularly where it is difficult to determine what the interests of the company are, because the conflict is not, in

\footnotetext{
109 (1887) 12 App. Cas. 589.

110 This is akin to the approach taken by Dixon J. in Peters'American Delicacy Co. Ltd. v. Heath (1939) 61 C.L.R. 457 in which he held that where an alternation of articles of a company has taken place and there is a conflict between the majority and the minority interests, the will of the majority should prevail except where no reasonable person could regard the alteration as a fair one to be made.

111 Companies Act 1985 s. 9.

112 Allen v. Gold Reefs of West Africa Ltd. [1900] 1 Ch. 656, 671 per Lindley M.R.
} 
fact, between the company and the shareholders, but between the majority and the minority shareholders. Very often in such circumstances, the company will have no interests against which the shareholders' decision can be judged. ${ }^{113}$ However, this difficulty should not arise in the situations discussed in this article, such as misappropriations of company property by directors, as the company will generally have a discernible interest. Whilst this will generally be the return of the property to the company, this need not always be the case if there are good practical reasons why it is not in the best interests of the company for a claim to be pursued, for instance, because of the potential injury to the reputation of the company or because the prospect of recovery would not justify the expense of litigation. Provided these factors are sufficient for a reasonable man to believe that non-recovery is in the best interests of the company, then any ratification could be treated as valid by the court.

In Australia the courts have already expanded the situations in which the shareholders are constrained by the court as to the manner of their voting beyond the ambit of alteration of articles. The courts there have required that shareholders should not use the powers conferred on them in a general meeting for an improper purpose when ratifying wrongdoing on the company's behalf. ${ }^{114}$ Although recognising that shareholders can, as individuals, exercise their votes for their own benefit, this has been held to be subject to the obligation on the majority shareholders in general meeting to use their powers bona fide for the benefit of the company as a whole. This has resulted in a prohibition on the use of this power to commit a fraud on the company, represented by the minority, in the sense of appropriating to themselves or to some of themselves, property, advantages or rights which belong to the company. The English courts have, as yet, not followed this lead, although there would be obvious advantages in them doing so. Such an approach makes it clear what the actual danger of this situation is: that the company's interests will be inadequately protected against the interests of those who act on the company's behalf. This is a danger which is obscured by the present transaction-based focus of the courts. Of course, the introduction of such a voting constraint would clearly conflict with the idea of a vote as a piece of property. ${ }^{115}$ However, this principle has already been avoided in relation to the alteration of a company's articles, where the shareholders are often acting on their own behalf,

113 Greenhalgh v. Arderne Cinemas Ltd. [1951] Ch. 286, 291 per Evershed M.R.; Peters' American Delicacy Co. Ltd. v. Heath (1939) 61 C.L.R. 457 per Dixon J.; Gambotto v. W.C.P. Ltd (1995) 16 A.C.S.R. 1; F.G. Rixon, "Competing Interests and Conflicting Principles: An Examination of the power of alteration of articles of association" (1986) 49 M.L.R. 446.

114 Nguli v. McCann (1953) 90 C.L.R. 425; Winthrop Investments Ltd. v. Winns (1975) 2 N.S.W.L.R. 666; Residues Treatment and Trading Co. Ltd. v. Southern Resources Ltd. (No. 4) (1988) 51 S.A.S.R. 196 and see E. Boros, Minority Shareholders' Remedies (Oxford 1995) p. 200 et seq.

115 North-West Transportation Co. Ltd v. Beatty (1887) 12 App. Cas. 589, 594 per Sir Richard Baggallay. 
to protect their own interests, ${ }^{116}$ and the development of section 459 Companies Act 1985 has also imposed constraints on what shareholders can do with their shares in certain circumstances. It is surely easier to justify the introduction of a requirement to vote bona fide in the best interests of the company when the shareholders are acting wholly on behalf of the company, in the context of ratification.

In addition, this type of voting constraint would not fall foul of the difficulties presented by Lord Russell's dicta in Regal (Hastings) since it would not prevent the directors voting their shares in support of the ratification of their own wrongdoing provided that a reasonable person would believe the ratification to be in the best interests of the company. On the facts of Regal this does appear to be the case. In Regal a company, A, owned a cinema and A's directors decided to acquire two others in order to sell all three as a going concern. A second company, B, was formed in order to take up the leases of the two cinemas. The lessor required the paid up capital of B to be $£ 5000$ and due to a lack of money on A's part, the directors and their friends took up a substantial number of B's shares. When all the shares in A and B were later sold, at substantial profit, in relation to $\mathrm{B}$, for the directors and $\mathrm{A}$, the new controllers of A sought to recover that profit from the directors. If a ratifying resolution had been passed prior to the sale by the shareholders (including the directors) then that ratification would be valid on this voting constraints test since it is possible for a reasonable man to believe that the wrongdoing allowed A to profit in a way which it would not otherwise have been able to do: the ratification of that wrong could therefore be regarded as being in the interests of the company. Compare Cook v. Deeks ${ }^{117}$ where it is difficult to see how the diversion to themselves by the directors of contracts which should have been taken up on behalf of the company could be regarded by a reasonable person as being in the company's best interests.

\section{CONCLUSION}

Given the confused nature of the law surrounding ratification, it is helpful to go back and consider the origins of the doctrine. It has been argued that the trust concept of release has not been adequately translated into a modern company context. In particular a gap has been left, that gap being the adequate protection of the company from the often conflicting interests of the shareholders who have been chosen by the courts to act for the company in this context. Although the courts have attempted to protect the company by investigating the nature of the wrongdoing which is being ratified, and categorising a ratification of that wrongdoing as invalid if certain

\footnotetext{
116 E.g., Greenhalgh v. Arderne Cinemas Ltd. [1951] Ch. 286.

117 [1916] 1 A.C. 554
} 
characteristics, such as fraud, are present in that wrongdoing, this has proved to be an inadequate basis of protection, primarily because the nature and extent of those relevant characteristics is unclear, making it uncertain in practice when the protection will be available. Focusing on the nature of the transaction merely obscures the important issue which is whether the company's representatives are in fact acting in the company's interests or in their own interests. The courts should, instead, focus on the manner in which the shareholders actually fulfil their representative role. Whilst various options are available, most are impractical or unhelpful, since they would involve the court in impossible analyses, or would fail to provide the protection which the company requires. A better solution would be for the English courts to follow the Australian example and analyse the shareholders' decision in order to determine whether the ratification is in the best interests of the company. This would not involve an assessment of the motivations of each individual shareholder but instead the shareholders' decision would be viewed as a whole. The issue of ratification could be left to a decision of the majority unless it could be said that no reasonable person could regard the decision taken as being in the best interests of the company. However, even if such a view is not taken up, it is clear that a fundamental review of ratification is long overdue, and if the Law Commission will not do so, it will be the courts who are left to grapple with ratification's tentacles. 